Tersedia online di:http://ejournal-balitbang.kkp.go.id/index.php/jkpi
e-mail:jkpi.puslitbangkan@gmail.com
JURNAL KEBIJAKANPERIKANANINDONESIA
Volume 11 Nomor 1 Mei 2019
p-ISSN: 1979-6366
e-ISSN: 2502-6550
Nomor Akreditasi Kementerian RISTEKDIKTI: 21/E/KPT/2018

\title{
KONSERVASI SUMBER DAYA UDANG WINDU (Penaeus monodon) DI PANTAI TIMUR ACEH, KABUPATEN ACEH TIMUR
}

\section{CONSERVATION OF INDIAN TIGER PRAWN (Penaeus monodon) RESOURCES IN EAST ACEH COAST, EAST ACEH REGENCY}

\author{
Didik Wahju Hendro Tjahjo*1, Dimas Angga Hedianto', Astri Suryandari", \\ Amula Nurfiarini' ${ }^{1}$, Zulkarnaen Fahmi ${ }^{1}$, Indriatmoko' dan Joni Hariyadi ${ }^{1}$ \\ 'Balai Riset Pemulihan Sumber Daya Ikan, Jl. Cilalawi No. 1 Jatiluhur, Purwakarta, Jawa Barat 41152, Indonesia \\ Teregistrasi I tanggal: 27Juli 2018; Diterima setelah perbaikan tanggal: 20 September 2019; \\ Disetujui terbit tanggal: 26 September 2019
}

\begin{abstract}
ABSTRAK
Udang windu (Penaeus monodon) merupakan salah satu komoditas udang utama dan mempunyai nilai ekonomi tinggi di perairan, Kabupaten Aceh. Saat ini laju eksploitasi udang windu sangat tinggi. Hal tersebut merupakan ancaman terhadap kelestarian sumber daya udang windu. Tujuan penelitian ini untuk mengkaji opsi pengelolaan konservasi udang windu di Aceh Timur. Kepadatan post larva Penaeidae berkisar antara 0-214 ind $/ 1.000 \mathrm{~m}^{3}$ dan kepadatan stok juvenil udang windu berkisar antara 686-1.875 ind $/ \mathrm{km}^{2}$, dimana kepadatan tertinggi di Kuala Arakundo dan Kuala Peureulak. Distribusi spasial kelimpahan udang windu berkisar antara 10-130 ekor $/ \mathrm{m}^{2}(10-$ $167.000 \mathrm{~g} / \mathrm{ha}$ ). Analisis aspek status pemanfaatan, degradasi habitat (penebangan liar, pembukaan tambak, dan sedimentasi), perkiraan dan evaluasi resiko, serta faktor-faktor yang mendukung diantaranya respon masyarakat dan kesiapan sistem sosial merupakan masukan dalam menentukan konservasi sumber daya udang windu. Oleh karena itu, dalam upaya menjamin kelestarian sumber daya udang windu di alam serta keberlanjutan usaha budidayanya, perlu dilakukan langkah-langkah pengelolaan dan konservasi sumber daya udang windu yang rasional, seperti (a) pengendalian dan pemulihan degradasi lingkungan melalui pengendalian erosi bagian hulu-hilir, dan menjaga dan merehabilitasi hutan mangrove, (b) pengendalian penyebaran penyakit dengan pendekatan kehati-hatian untuk pengembangan budidaya udang vanamei, (c) pengendalian penangkapan juvenil udang windu melalui pelarangan beroperasi alat tangkap sejenis trawl (pukat langgih dan pukat layang), dan (d) revitalisasi dan pengembangan kelembagaan nelayan.
\end{abstract}

Kata Kunci: Udang windu; pengelolaan; konservasi; perairan Aceh Timur

\begin{abstract}
Indian tiger prawn (Penaeusmonodon) is one of the main shrimp commodities and has high economic value. East coastal waters of East Aceh district is known as one of the main producer of tiger prawns with the best quality. On the other hand the rate of exploitation of tiger shrimp is very high. This issue is therefore need to be a addressed further. The purpose of this study is, therefore, to assess the management activities needed to conserve tiger shrimp in East Aceh. Penaeidae post larvae density in Aceh Timur ranges from 0-214 ind $/ 1,000 \mathrm{~m}^{3}$ and juvenile stock density ranges from $0,245-49,419 \mathrm{~kg} / \mathrm{km}^{2}$, where the highest density is in Kuala Arakundo and Kuala Peureulak. The Spatial Abundance Distribution of indian tiger prawn ranges from 10 to 130 ind./m² (10-167,000 g/ ha). Analysis of aspects of utilization status, habitat degradation (illegal logging, sedimentation, land clearing for aquaculture), risk estimation and evaluation, and factors are inputthat support conservation of tiger shrimp resources. Therefore, in an effort to ensure the sustainability of tiger shrimp resources in the wild and the sustainability of its cultivation business, it is necessary to take steps to manage and conserve rational tiger shrimp resources.such as (a) controlling and restoring environmental degradation through upstream-downstream erosion control, and safeguarding and rehabilitating mangrove, (b) controlling the spread of diseases with precautionary approach to the development of
\end{abstract}


vanamei shrimp farming, (c) controlling the capture of indian tiger prawn juveniles through the prohibition operates of bottom trawling (pukat langgih and pukat layang), and (d) fisherman revitalization and institutional development.

Keywords: Indian tiger prawn; management; conservation; East Aceh waters

\section{PENDAHULUAN}

Udang merupakan komoditas perikanan utama andalan ekspor Indonesia dengan rata rata nilai ekspor 1,66 milyar dollar Amerika pertahunnya (Pusdatin-KKP, 2018). Habitat udang windu Indonesia tersebar mulai dari perairan bagian barat hingga timur Indonesia (Chan, 1998). Perairan Aceh Timur merupakan salah satu penghasil udang windu di Indonesia. Kualitas induk udang windu dari perairan Aceh Timur dikenal memiliki variasi genetik yang tinggi (Sugama et al., 2002), tumbuh cepat dan tahan terhadap virus (Haryanti et al., 2009), serta memiliki performa reproduksi yang baik khususnya udang windu jantan (Lante et al., 2014).Karena kualitas induk yang tinggi tersebut menyebabkan induk-induk udang windu dari perairan Aceh Timur banyak dijadikan induk penghasil benih pada pantai-pantai benih yang tersebar di Indonesia.

Penangkapan udang windu di perairan Aceh timur dilakukan dengan menggunakan jaring tiga lapis (trammel nets) dengan sasaran induk udang windu yang akan dijual hidup sebagai indukan untuk budidaya, sedangkan untuk udang yang dijual sebagai udang konsumsi. Penangkapannya lebih dominan menggunakan pukat layang serta langgih (mini bottom trawl).

Tingginya permintaan udang windu mengakibatkan penangkapan induk udang windu dengan trammel nets cukup intensif, selain itu adanya kecenderungan penangkapan stadia juvenil di estuaria hingga pesisir dengan alat tangkap pukat layang dan langgih (mini bottom trawl) (Hedianto et al., 2016) merupakan ancaman bagi kelestarian sumber daya udang windu di alam.

Untuk menjamin kelestarian sumber daya udang windu di alam serta keberlanjutan usaha budidayanya diperlukan upaya konservasi di beberapa perairan sekitar Aceh Timur yang merupakan daerah potensial sebagai penghasil induk udang windu yang unggul secara performa dan genetik. Tujuan penelitian ini untuk mengkaji langkah-langkah pengelolaan konservasi udang windu di Aceh Timur. Penelitian mengenai kawasan konservasi udang windu tersebut sejalan dengan program pemerintah Kabupaten Aceh Timur yang saat ini sedang berupaya menyiapkan zonasi kawasan konservasi perairan dan pengembangan kawasan minapolitan sehingga diharapkan hasil penelitian ini dapat mendukung program pemerintah daerah.

\section{BAHASAN}

\section{Status Pemanfaatan Udang}

Permintaan udang windu baik untuk konsumsi maupun induk sangat tinggi, menyebabkan penangkapannya cenderung meningkat. Data statistik Kabupaten Aceh Timur tahun 2010-2017 menunjukkan kecenderungan peningkatan jumlah nelayan trammel net yang menangkap udang windu rata rata sebesar 38\%/tahun (BPS Aceh Timur, 2010-2018).

Selain melalui penangkapan upaya pemenuhan permintaan pasar juga dilakukan melalui budidaya. Kegiatan budidaya membutuhkan benih baik kuantitas maupun kualitas tinggi dan tersedia secara kontinyu. Di lain pihak, panti-panti benih tersebut masih sangat tergantung pada induk udang windu dari alam, sehingga kegiatan penangkapan induk udang windu semakin intensif, yang mengakibatkanpopulasi udang windu di alam cenderung semakin menurun (Gambar 1).

Penangkapan udang windu menggunakan pukat layang dan langgih banyak dilakukan di perairan estuari hingga lepas pantai. Jumlah alat tangkap jenis ini mencapai lebih dari 100 unit untuk satu wilayah Kecamatan Julok. Kegiatan penangkapan yang terus menerus dengan alat tangkap yang bersifat destruktif dan tidak selektif dapat mengancam keberlanjutan stok udang windu di alam. Berdasarkan data statistik perikanan Aceh Timur, produksi tangkapan udang windu dalam delapan tahun terakhir (2010-2018) berfluktuasi, pada 2010-1012 cenderung menurun namun kemudian terus meningkat hingga 2018 dengan peningkatan rata rata 9,44-34,89\% (Gambar 2).

Hasil analisa perkiraan dan evaluasi risiko. Pukat layang dan langgih untuk menangkap udang windu biasa dioperasikan di daerah inner litoral (daerah pesisir sekitar 0-2 mil). Kedua alat tangkap tersebut mempunyai selektivitas tangkap terhadap ukuran udang windu lebih kecil dibandingkan ukuran udang tersebut pertama kali matang gonad $\left(\mathrm{L}_{\mathrm{m}}\right)$. Hal ini berarti udang akan tertangkap belum sempat memijah, sehingga alat tangkap tersebut merupakan ancaman yang nyata bagi kelestarian populasi udang windu di Aceh Timur. Hasil penelitian Suryandari et al. (2018) menunjukkan bahwa nilai $L_{m}$ dari udang windu betina pada panjang karapas $46 \mathrm{~mm}$, sedangkan ukuran pertama kali tertangkap $\left(\mathrm{L}_{\mathrm{c}}\right)$ adalah $40 \mathrm{~mm}$ (Gambar 3). Nilai selektivitas tangkap bottom trawl $\left(\mathrm{L}_{c}\right)$ berada 
di depan nilai pertama kali matang gonad $\left(\mathrm{L}_{\mathrm{m}}\right)$ dari udang windu (Tjahjo et al., 2016). Hal ini cukup membahayakan populasi udang windu di Aceh Timur, karena udang tertangkap terlebih dahulu sebelum dapat memijah (Hedianto et al., 2016).

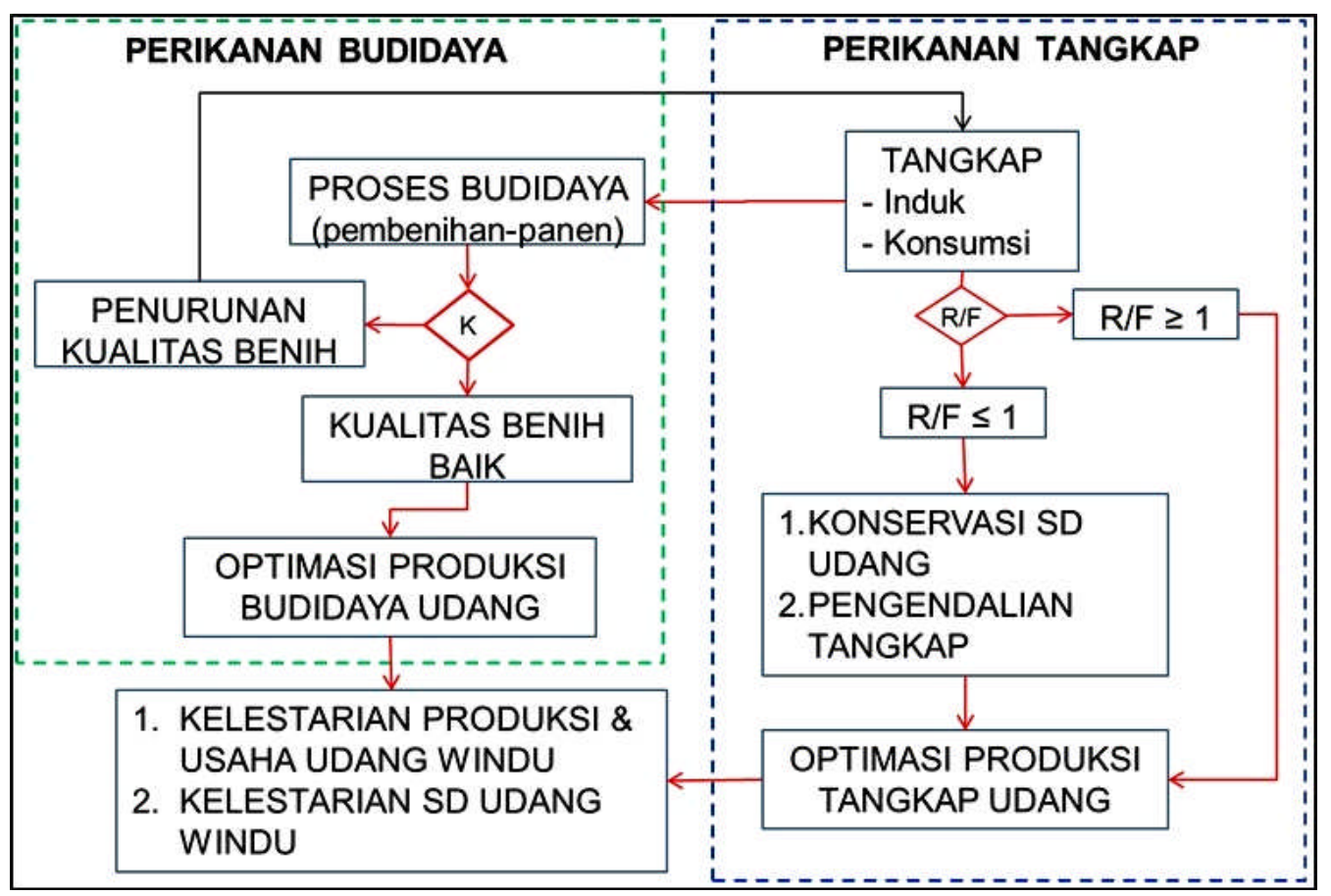

Gambar 1. Pendekatan masalah pemanfaatan udang windu.

Figure 1. Problem approach of Indian tiger prawn utilization.

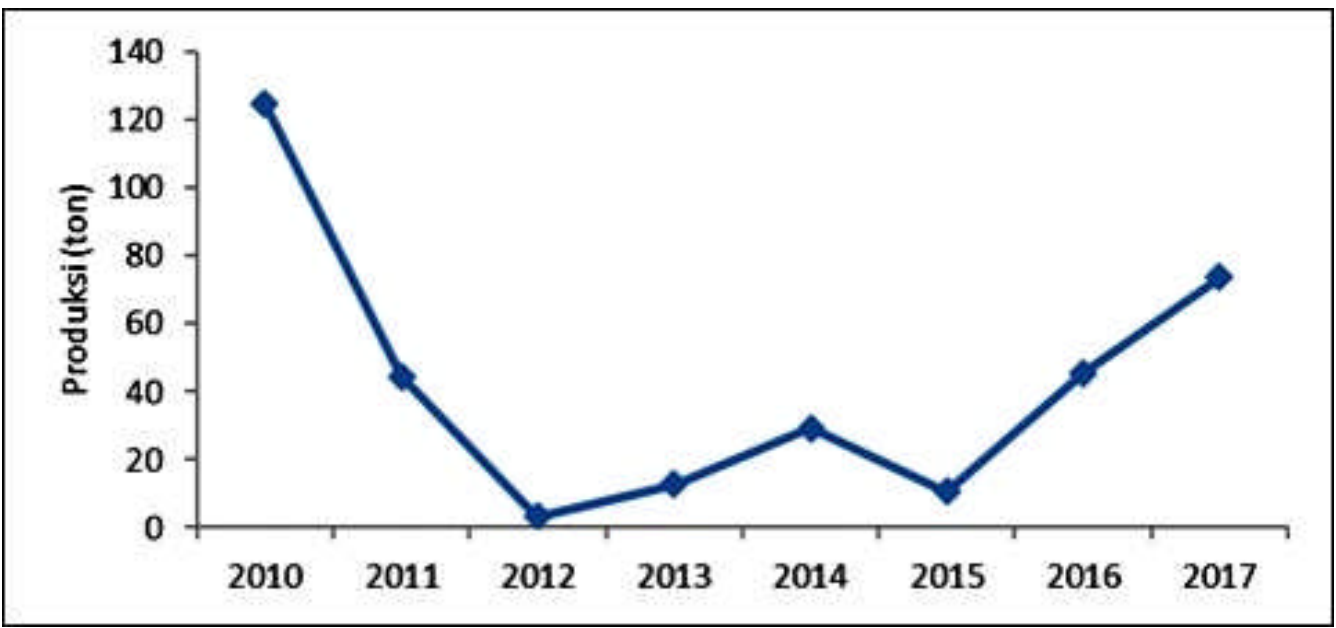

Gambar 2. Perkembangan produksi udang windu (Penaeus monodon) di Kabupaten Aceh Timur.

Figure 2. Development of tiger prawn (Penaeus monodon) production in East Aceh Regency. 


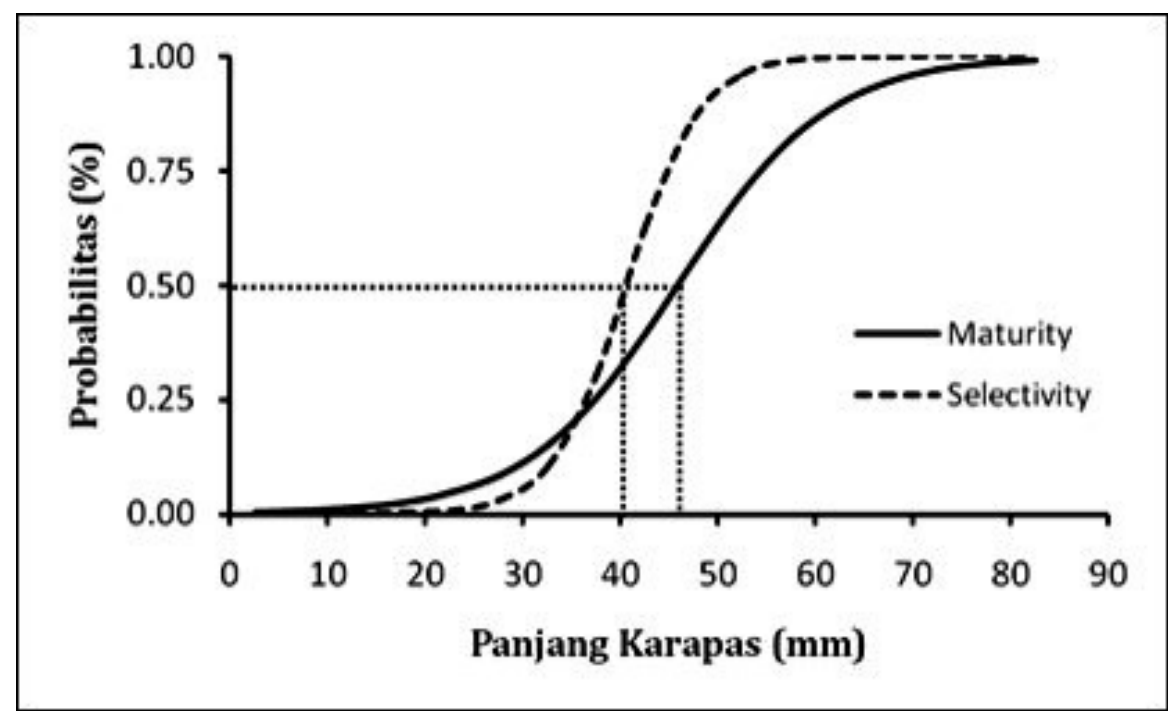

Gambar 3. Ukuran pertama kali tertangkap $\left(L_{c}\right)$ dan matang gonad $\left(L_{m}\right)$ udang windu di perairan Aceh Timur dengan alat tangkap trawl (Suryandari et al., 2018).

Figure 3. The size of first captured $\left(L_{c}\right)$ and gonad maturity $\left(L_{m}\right)$ of tiger shrimp in the waters of East Aceh by trawling fishing gear (Suryandari et al., 2018).

Kondisi tersebut lebih diperparah dengan laju eksploitasi tahunan udang windu yang tinggi dan berada pada kondisi lebih tangkap (over exploited). Laju ekploitasi baik untuk udang betina maupun jantan masing-masing telah mencapai 0,78 dan 0,62 . Hal tersebut berarti upaya pemanfaatan udang windu jantan maupun betina menggunakan alat tangkap bottom trawl di perairan Aceh Timur sudah berada pada kondisi kelebihan tangkap dan masing-masing sebesar $24 \%$ dan $56 \%$ dari batas nilai optimum ( $E=$ 0,5) (Hedianto et al., 2016). Kondisi tersebut diperparah dengan hasil tangkapan didominasi oleh udang yang belum layak tangkap $\left(\mathrm{L}_{c}<\mathrm{L}_{m}\right)$. Hal tersebut sama dengan kondisi penangkapan udang putih (Penaeus merguiesis) di perairan Sampit, Kalimantan Tengah (Nurdin \& Kembaren, 2015) dan udang jerbung (Penaeus merguiensis) di perairan Dolak (Laut Arafura) (Hargiyatno et al., 2013). Pada kasus yang sama terlihat dari hasil penelitian Wedjatmiko (2009) bahwa udang betina lebih rentan atau lebih mudah tertangkap.

Laju eksploitasi yang lebih tangkap (over-fishing) dari bottom traw/berpengaruh langsung terhadap hasil tangkapan dan ukuran induk yang tertangkap oleh trammel nets. Hal ini karena hasil tangkapan udang windu yang tinggi di daerah asuhan sehingga mengakibatkan rekrutmen induk udang terhambat. Pada akhirnya ketersediaan induk udang windu di perairan Aceh Timur dapat menurun, bahkan punah apabila kondisi kelebihan tangkap untuk bottom trawl tidak segera dilakukan pengendalian dan pembatasan. Udang windu di perairan kabupaten Aceh Timur mempunyai laju eksploitasi yang jauh lebih tinggi $(E=0,62-0,78)$ jika dibandingkan dengan udang windu di perairan Tarakan (Kalimantan Timur) $(E=0,56)$ (Kembaren \& Nurdin, 2013).

\section{Degradasi Habitat dan Penyakit Udang}

Hutan mangrove banyak dijumpai di pantai yang landai dengan muara sungai yang berlumpur dengan kondisi perairan yang tenang dan terlindung dari ombak. Fungsi penting hutan mangrove antara lain:(a) sebagai sumber makanan bagi berbagai macam hewan laut;(b) melindungi pantai dari erosi, gelombang angin, dan ombak; (c) sebagai daerah asuhan (nursery ground); dan (d) pemijahan (spawning ground) bagi udang, ikan dan kerang-kerangan (Dartoyo, 2004; Nurfiarini \& Adrianto, 2015). Toro \& Sukardjo (1990) dan Motoh (1985) menyimpulkan bahwa hasil perikanan udang regional berkorelasi dengan luas hutan mangrovenya.

Hutan mangrove merupakan habitat penting berbagai jenis krustase termasuk beberapa jenis udang yang memiliki nilai ekonomis tinggi (Zakirah et al., 2003). Kondisi hutan mangrove Kabupaten Aceh Timur seluas 36.064 ha atau $50 \%$ total lahan sudah tergolong sangat kritis, $40 \%$ (28.729 ha) tergolong kritis dan hanya $10 \%$ (7.548 ha) yang tidak kritis (Gambar 3). Sebaran lahan yang tidak kritis paling luas terdapat di Kecamatan Bireum Bayeun dan Rantau Selamat masing-masing 4.756 ha dan 1.189 ha (Fitri \& Iswahyudi, 2010). Degradasi ekosistem mangrove terjadi selain adanya faktor eksternal yakni sedimentasi dari lahan hulu yang dalam jangka panjang berdampak pada perubahan formasi 
mangrove, juga faktor internal berupa alih fungsi lahan menjadi tambak, areal pertanian dan penebangan pohon mangrove, yang berpengaruh nyata terhadap percepatan kerusakan hutan mangrove perairan tersebut. Degradasi ekosistem mangrove yang semakin meningkat mengakibatkan keberadaan dan perkembangan populasi udang windu semakin terdesak. Dalam jangka panjang, kondisi tersebut dapat menurunkan kualitas keunggulan udang windu, maupun daya dukung perairan tersebut untuk pertumbuhan dan perkembangan udang tersebut di perairan Timur Aceh.
Penyakit IHHNV (Infectious Hypodhermal Hematophoietic Necrosis Virus) menurut Maskur et al. (2014) disebabkan oleh Parvovirus. IHHNV merupakan penyakit serius untuk udang Penaeidae. Pembawa penyakit ini adalah jenis udang Penaeidae dari jenis Litopenaeus spp. terutama $L$. stylirostris. Penularan virus ini dapat terjadi secara vertikal dan horizontal. IHHNV relatif cepat dan efisien menular melalui luka akibat kanibalisme udang, terutama pada periode lemah (molting) maupun proses ko-habitasi melalui transfer dalam air.

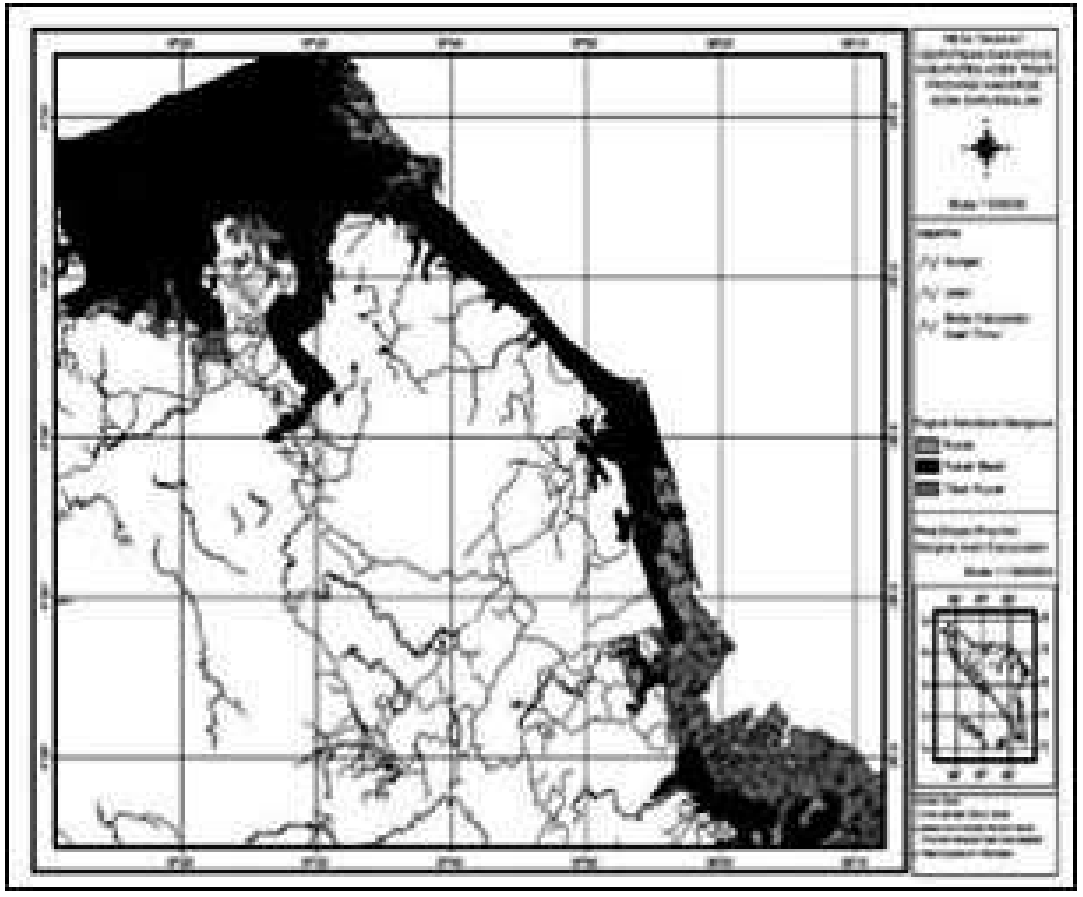

Gambar 4. Peta Tingkat Kekritisan Lahan pada Hutan Mangrove di Aceh Timur (Fitri \& Iswahyudi, 2010).

Figure 4. Map of Land Critical Level on Mangrove Forest in East Aceh (Fitri \& Iswahyudi, 2010).

Infeksi virus ditemukan tidak hanya pada udang budidaya tetapi juga pada udang liar. Virus yang berbeda telah ditemukan pada udang liar misalnya pada penelitian yang dilakukan di perairan Brunei, untuk P. monodon terditeksi ada IHHNV (Infectious hypodermal and hematopoeitic necrosis virus) paling sering terdeteksi $(19,6 \%)$, diikuti oleh MBV (monodon baculovirus) (7,4\%), HPV (hepatopancreatic parvovirus) (3,8\%), dan MoV (Mourilyan virus) $(0,9 \%)$ (Ganjoor, 2015). Di perairan Aceh Timur, adanya penyebaran virus IHHNV pada udang windu diduga berkaitan dengan adanya aktivitas budidaya udang vanamei (Litopenaeus vannamel) yang ada di daerah Julok, sedangkan di daerah Peudawa tidak ada aktivitas budidaya udang vanamei (Suryandari et al., 2015). Penyebaran virus IHHNV pada udang windu ini terus meluas seiring dengan perkembangan dan penyebaran usaha budidaya tambak udang vanamei di Kabupaten Aceh Timur. Hal tersebut diperparah dengan perkembangan dan penyebaran usaha budidaya tambak udang vanamei di Kabupaten Aceh Timur cenderung meningkat dengan pesat. Jenis penyakit WSSV (White Spot Syndrome Virus) adalah penyakit yang umum terjadi pada udang windu maupun jenis udang Penaeidae lainnya. WSSV adalah agen penyebab penyakit yang menyebar luas terkait dengan tingkat kematian yang tinggi pada udang budidaya, dan menyebabkan mortalitas hingga 100\% (Ganjoor, 2015).Produksi udang mengalami penurunan yang sangat drastis dan sampai saat ini permasalahan tersebut belum dapat diatasi sepenuhnya. Sejak munculnya WSSV (white spot syndrome virus), agen penyakit bintik putih, produksi udang mengalami penurunan menjadi hanya sekitar 50.000 ton pada tahun 2000 dari sekitar lebih dari 200.000 ton pada tahun 1994/1995 (Anshary \& Sriwulan, 2016). 


\section{Faktor-Faktor yang Mendukung Konservasi Sumber Daya Udang Windu}

Sebaran dan kelimpahan post larva Penaeidae tersebar di seluruh daerah pesisir Aceh Timur, mulai dari Madat hingga Rantau Selamat. Kepadatan post larva Penaeidae berkisar antara 0-214 ind $/ 1.000 \mathrm{~m}^{3}$. Daerah dengan kepadatan tertinggi terdapat di daerah Kuala Arakundo dan sekitarnya serta Kuala Peureulak. Kuala Geulumpang (159 ind/1.000 $\mathrm{m}^{3}$ ), Sungai Peureulak Hilir (100 ind $/ 1.000 \mathrm{~m}^{3}$ ), Sungai Peureulak Tengah (150 ind $/ 1.000 \mathrm{~m}^{3}$ ) dan Kuala Jengki Muara (215 ind $/ 1.000 \mathrm{~m}^{3}$ ) (Tjahjo et al., 2014; Suryandari et al., 2015; Suryandari et al., 2018; Tjahjo et al., 2016). Sebagai pembanding, kelimpahan larva udang total di Laguna Segara Anakan berkisar antara 121-117.064 ind/1000 $\mathrm{m}^{3}$ (Wagiyo \& Amri, 2015).

Kepadatan stok juvenil udang windu berkisar antara 0,245-49,419 kg/km² (Tjahjo et al., 2014; Suryandari et al., 2015; Suryandari et al., 2018; Tjahjo et al., 2016). Daerah dengan kepadatan stok tertinggi terdapat di daerah Kuala Arakundo dan Kuala Peureulak, kemudian disusul daerah Kuala Parek dan Kuala Bayeun. Juvenil udang windu dan hampir keseluruhan udang Penaeidae membutuhkan masukan air tawar sebagai daerah asuhannya. Kelimpahan udang windu di Aceh Timur tersebut relatif lebih rendah dibandingkan kelimpahan udang penaeid di Laguna Segara Anakan dan perairan Semarang. Kelimpahan udang penaeid di Laguna Segara Anakan berkisar 8-336 ind/1000 $\mathrm{m}^{2}$ dengan rata-rata $122 \mathrm{ind} /$ $1000 \mathrm{~m}^{2}$ pada tahun 2012 (Tjahjo \& Suryandari, 2013), dan pada tahun 2013 kelimpahan krustacea total di di perairan tersebut berkisar antara 441-6.865 ind./ $10^{4} \mathrm{~m}^{3}$ dan udang windu berkisar $3-723$ ind. $/ 10^{4} \mathrm{~m}^{3}$ (Wagiyo \& Amri, 2015). Di Pantai Semarang, kelimpahan udang penaeid mencapai 256 ind/ha pada tahun 2001 (Promonowibowo, 2003).

Udang windu menujukkan pola distribusi secara horizontal yang relatif merata di sepanjang pantai Timur dari Kabupaten Aceh Timur hingga Kabupaten Aceh Tamiang, dan kelimpahan induk udang windu sepanjang perairan laut tersebut masih tergolong tinggi. Hal tersebut menunjukkan bahwa karakteristik masing-masing daerah pengamatan tersebut relatif hampir sama. Jadi tidak ada satu daerah atau beberapa daerah yang mempunyai karakteristik yang khas dan paling sesuai untuk pertumbuhan udang windu, atau mempunyai keutuhan ekosistem bagi udang windu. Pada dasarnya, udang ini mempunyai sifat dapat menyesuaikan diri dengan makanan yang tersedia di lingkungannya dan tidak bersifat memilih, tetapi hutan mangrove yang memiliki dasar perairan berupa lumpur, merupakan habitat yang paling disukai
(Tjahjo \& Suryandari, 2016), karena ekosistem ini mampu menyediakan makanan yang tidak pernah putus dan tempat perlindungan (Pratiwi, 2008). Oleh karena itu, daerah yang perlu dikonservasi untuk pertumbuhan juvenil udang windu adalah Kuala Simpang Ulim, Kuala Sungai Arakundo dari Hulu hingga muara, sodetan Sungai Arakundo, Kuala Geulumpang, Kuala Sungai Peureulak dari hulu hingga muara, Kuala Sungai Parek, Calok Nipah, Kuala Leugeu, Kuala Sungai Rantau Selamat, Kuala Berangau, Kuala Sungai Udang dan Kuala Peunaga (Gambar 5).

Hal tersebut disebabkan dalam penetapan daerah konservasi salah satunya harus mempunyai keutuhan ekosistem (integritas ekologi) bagi target spesies (Nurfiarini, 2015). Selanjutnya Reza (2009) menjabarkan bahwa integritas ekologi terkait dengan keutuhan sebuah ekosistem dalam keberadaan dan fungsinya, mencakup aspek fisik, kimia dan biologi sebagai satu kesatuan integritas ekologi. Bridgewater et al. (2015) menyatakan bahwa dua aspek yang perlu dipertimbangkan pada pemahaman integritas ekologi: keanekaragaman hayati dan habitat. Kedua aspek ini saling berhubungan dimana dalam habitat yang baik, banyak spesies biota dapat bertahan hidup dan berkembang dengan baik.

Distribusi kelimpahan induk udang windu sepanjang laut Kabupaten Aceh Timur hingga Kabupaten Aceh Tamiang termasuk tinggi. Berdasarkan survey akustik, distribusi spasial kelimpahan udang windu (Oktober 2015) menunjukkan bahwa kelimpahan area udang windu di pesisir Aceh Timur berkisar antara $10-130$ ekor/ $\mathrm{m}^{2}$, dengan nilai rata-rata sebesar $37 \mathrm{ekor} / \mathrm{m}^{2}$, dan pada bulan April 2016 berkisar antara $10-20$ ekor/ $\mathrm{m}^{2}$, dengan nilai rata-rata sebesar $4 \mathrm{ekor} / \mathrm{m}^{2}$ (Fahmi et al., 2017). Distribusi berdasarkan biomasnya berkisar antara 10-167.000 g/ha, dengan nilai ratarata sebesar $50.778 \mathrm{~g} / \mathrm{ha}$ (Oktober 2015), dan berkisar antara $8.500-65.900 \mathrm{~g} / \mathrm{ha}$, dengan nilai rata-rata sebesar $36.845 \mathrm{~g} / \mathrm{ha}$ (April 2016). Rata-rata kepadatan stok udang windu tersebut lebih tinggi dibandingkan rata-rata kepadatan udang total di Laut Jawa $\left(21,34 \pm 16,81 \mathrm{~kg} / \mathrm{km}^{2}\right)$ (Tirtadanu et al., 2016).

Populasi udang windu di Aceh Tamiang, Langsa, Peudawa, dan Julok memiliki variasi genetik yang rendah. Hasil penelitian menunjukkan bahwa Julok merupakan salah satu kawasan yang memiliki populasi tersendiri berdasarkan jarak genetiknya, sedangkan populasi di Aceh Tamiang, Langsa, dan Peudawa memiliki kesamaan genetik. Namun demikian, perbedaan genetik yang ditemukan tidak berbeda nyata (Indriatmoko et al., 2017). 


\section{Langkah-Langkah Pengelolaan dan Konservasi Sumber Daya Udang Windu}

Beberapa faktor yang mendukung perlunya pengembangan pengelolaan dan konservasi udang windu untuk pelestariannya di perairan pantai Timur Aceh adalah keinginan dan semangat masyarakat dan Pemda untuk mengembangkan kawasan konservasi sumber daya udang windu. Beberapa tahun ini hasil tangkapan udang windu menurun dengan dratis, baik kuantitas maupun kualitasnya, jika dibanding beberapa tahun yang lalu jumlah nelayan yang beroperasi jauh lebih tinggi dengan hasil tangkapan per nelayan juga lebih tinggi (hasil wawancara dengan beberapa panglima laot). Dipihak lain sumber daya ikan di perairan tersebut sebagai tumpuan harapan utama baik saat ini maupun masa depan bagi nelayan di sekitarnya. Kondisi tersebut yang menyadarkan masyarakat nelayan pentingnya arti pemulihan dan konservasi sumber daya udang windu.

\section{A. Langkah-langkah pengelolaan sumber daya udang tersebut, meliputi:}

1. Pengendalian dan pemulihan degradasi lingkungan yang meliputi:

a) Pengendalian erosi dari hulu hingga hilir, dengan kegiatan meliputi:(a) penghijauan lahan-lahan kritis bagian hulu dan sepadan sungai, (b) pembangunan waduk ataupun cek dam, dan (c) memperlancar laju sirkulasi air di bagian muara sungai melalui pengerukan dasar perairan dari mulut muara sungai.

b) Memelihara dan menjaga ekosistem hutan bakau dengan kegiatannya antara lain:

- Meningkatkan persepsi masyarakat mengenai fungsi ekologi ekosistem mangrove,

- Peningkatan peran serta masyarakat dalam pengendalian pemanfaatan vegetasi mangrove,

- Peningkatan peran serta masyarakat dalam rehabilitasi kawasan hutan mangrove,

- Perlu perbaikan rehabilitasi mangrove dari monospesies kemulti spesies sesuai dengan kesesuaian lahan untuk lokasi penanaman,

- Peningkatan peran serta masyarakat dalam pengawasan, dan penegakan peraturan perundang-udangan dan pemberlakuan sangsi yang tegas.

2. Pengendalian penyebaran virus IHHNV pada udang windu dan udang lokal lainnya, diharapkan peran aktif pemeritah daerah dan masyarakat melarang pengembanganan dan/ atau budidaya udang vanamei. Pengusaha yang semula membantu pembudidaya dengan sewa tambak, benih udang venamei, pakan dan pemasarannya. Bapeda setuju pola bantuan pengusaha tersebut tetapi benihnya udang windu bukan udang venamei.

3. Pengendalian penangkapan juvenil udang windu di perairan pantai Timur, melalui pelarangan beroperasinya alat tangkap pukat langgih dan pukat layang, karena dalam satu kapal penangkapan di Aceh Timur umumnya ada 2 sampai 3 jenis alat tangkap. Kondisi pelarangan tersebut telah diterapkan di Kabupaten AcehTamiang dan masyarakat nelayan sendiri secara aktif mengawasi pelaksanaan aturan tersebut. Hasil wawancara dengan masyarakat nelayan bahwa secara umum masyarakat nelayan ( $80 \%$ ) setuju untuk tidak menggunakan pukat langgih dan pukat layang (bottom traw).

\section{B. Langkah-langkah konservasi sumber daya udang windu, antara lain:}

Salah satu aspek yang diperlukan dalam pengembangan konservasi sumber daya udang windu adalah ada kehendak bersama (common will) masyarakat untuk melestarikan sumber daya perikanannya. Hal tersebut terbukti bahwa masyarakat pesisir menunjukkan keperduliannya dan tingkat kesiapan serta kesediaan untuk mengelola sumberdayanya secara lebih bertanggungjawab (Tabel 1). Hasil penilaian persepsi masyarakat dengan menggunakan pendekatan skala 1-5 (Yudiantari, 2002) terhadap rencana pengembangan kawasan perlindungan induk udang berkisar antara 3,72-4,59, dimana skor tertinggi pada indikator persepsi pembentukan lembaga pengelola.

Pada indikator tersebut diperoleh bahwa 59\% responden (Nurfiarini et al., 2017) menyatakan sangat penting dengan skor sebesar 4,59. Hal ini berarti masyarakat sangat setuju apabila pengembangan konservasi dapat diiringi dengan pembentukan lembaga pengelolanya, sehingga ada wadah yang merancang mekanisme kerja serta bertanggungjawab terhadap segala hal yang berkaitan dengan jalannya program pengembangan (Direktorat Konservasi kawasan dan Jenis Ikan, 2012). Keberadaan lembaga pengelola sekaligus berfungsi dalam mengukur tingkat efektifitas pengelolaan sebuah kawasan perlindungan sumber daya (Direktorat Konservasi kawasan dan Jenis Ikan, 2012). Meskipun demikian, keberadaan lembaga tersebut diharapkan dapat tetap bersinergi dengan kelembagaan lokal yang ada di wilayah mereka. 
Tabel 1. Skala sikap hasil penggalian persepsi masyarakat terhadap rencana pengembangan kawasan perlindungan induk udang (dimodifikasi dari Yudiantari, 2002)

Table 1. The attitude scale of the results public perception to development plan adult shrimp protection area (modified from Yudiantari, 2002).

\begin{tabular}{|c|c|c|c|}
\hline No. & Indikator Persepsi & $\begin{array}{l}\text { Nilai } \\
\text { Skala } \\
\text { Sikap }\end{array}$ & $\begin{array}{l}\text { Kesimpulan } \\
\text { Sikap }\end{array}$ \\
\hline 1. & Nilai penting sumber daya udang & 4,25 & Sangat mendukung/setuju \\
\hline 2. & $\begin{array}{l}\text { Kesediaan menjaga kelestarian } \\
\text { sumberdaya }\end{array}$ & 3,72 & Mendukung/setuju \\
\hline 3. & $\begin{array}{l}\text { Rencana pengembangan konservasi/area } \\
\text { perlindungan }\end{array}$ & 4,12 & Mendukung/setuju \\
\hline 4. & $\begin{array}{l}\text { Keberadaan kearifan lokal dalam yang } \\
\text { tetap dilestarikan dalam menunjang } \\
\text { pengembangan konservasi }\end{array}$ & 4,28 & Sangat mendukung/setuju \\
\hline 5. & $\begin{array}{l}\text { Pentingnya keterlibatan masyarakat dalam } \\
\text { pengembangan konservasi }\end{array}$ & 4,02 & Mendukung/setuju \\
\hline 6. & $\begin{array}{l}\text { Kesediaan peran serta aktif dalam } \\
\text { mengelola calon kawasan konservasi }\end{array}$ & 4,07 & Mendukung/setuju \\
\hline 7. & $\begin{array}{l}\text { Pembentukan lembaga pengelola } \\
\text { kawasan konservasi }\end{array}$ & 4,59 & Sangat mendukung/setuju \\
\hline
\end{tabular}

Sumber daya udang perlu mendapat perhatian yang serius dengan upaya-upaya pengelolaan yang lebih baik, apalagi sumber daya udang sangat rentan terhadap dampak penangkapan dan degradasi lingkungan mengingat sifatnya yang memiliki ruaya yang sempit, aktivitasnya rendah dan kawanan yang relatif kecil (Suman \& Umar, 2010). Pantai timur Kabupaten Aceh Timur memenuhi persyaratan keutuhan ekosistem (integritas ekologi), kesiapan pemanfaat (integritas sosial), dan keterkaitan antara keduanya (konektifitas sosial-ekologi) (Nurfiarini, 2015).Konektifitas sosial-ekologi ditunjukkan oleh nelayan jaring lapis yang mendominasi wilayah sentra udang, pola pemanfaatan sumberdaya, yakni nelayan menerapkan sistem penangkapan berselang (satu minggu menangkap, satu minggu libur). Sehingga langkah-langkah pengembangan Konservasi sumber daya udang windu di perairan perairan pantai Timur, Kabupaten Aceh Timur. Status konservasi sumber daya udang windu yang sesuai di perairan ini adalah "Tipe Perlindungan Terbatas", baik terhadap daerah asuhan maupun daerah induk/pemijahannya. Perlindungan terbatas yang dimaksudkan meliputi:

- Perlindungan berdasarkan ukuran tertentu

- Perlindungan berdasarkan wilayah sebaran tertentu

- Perlindungan berdasarkan periode waktu tertentu

1. Perlindungan terbatas berdasarkan ukuran tertentu bertujuan melindungi udang windu yang belum dewasa yang tinggal di muara sungai hingga perairan pantai. Daerah asuhan dan pembesaran (nursery ground) udang windu di perairan Aceh Timur terdapat di dua lokasi utama, yaitu (1) daerah sodetan Arakundo-Kuala Arakundo-Kuala Geulumpang seluas 17.030 ha, dan (2) Kuala Peureulak 8.928 ha (Gambar 5). Area Kuala Arakundo juga merupakan daerah asuhan utama untuk jenis udang Penaeid lainnya yang domiman di Perairan Aceh Timur, yaitu Metapenaeus dobsoni (Hedianto et al., 2017). Sesuai dengan hasil kajian kelimpahan juveniludang, maka waktu untuk penutupan penangkapan juveniludang windu adalah bulan Febuari-Maret untuk daerah sodetan Arakundo-Kuala Arakundo-Kuala Geulumpang, dan Juli-Agustus untuk Kuala Peureulak.

2. Perlindungan terbatas diberlakukan juga terhadap induk udang windu bertujuan untuk melindungi induk betina udang windu yang akan melepaskan telurnya yang telah dibuahi oleh sperma induk jantan, lokasinya agak ke arah tengah (jarak dari garis pantai berkisar antara 2-12 mil) dengan kedalaman 20-50 m. Penutupan penangkapan induk udang windu pada bulan April untuk daerah Madat (Krueng Too)-Arakundo (luas $32.810 \mathrm{ha}$ ) dan Langsa-Aceh Tamiang (25.250 ha), serta September untuk daerah Peudawa- Peureulak seluas 46.710 ha (Gambar 6). 


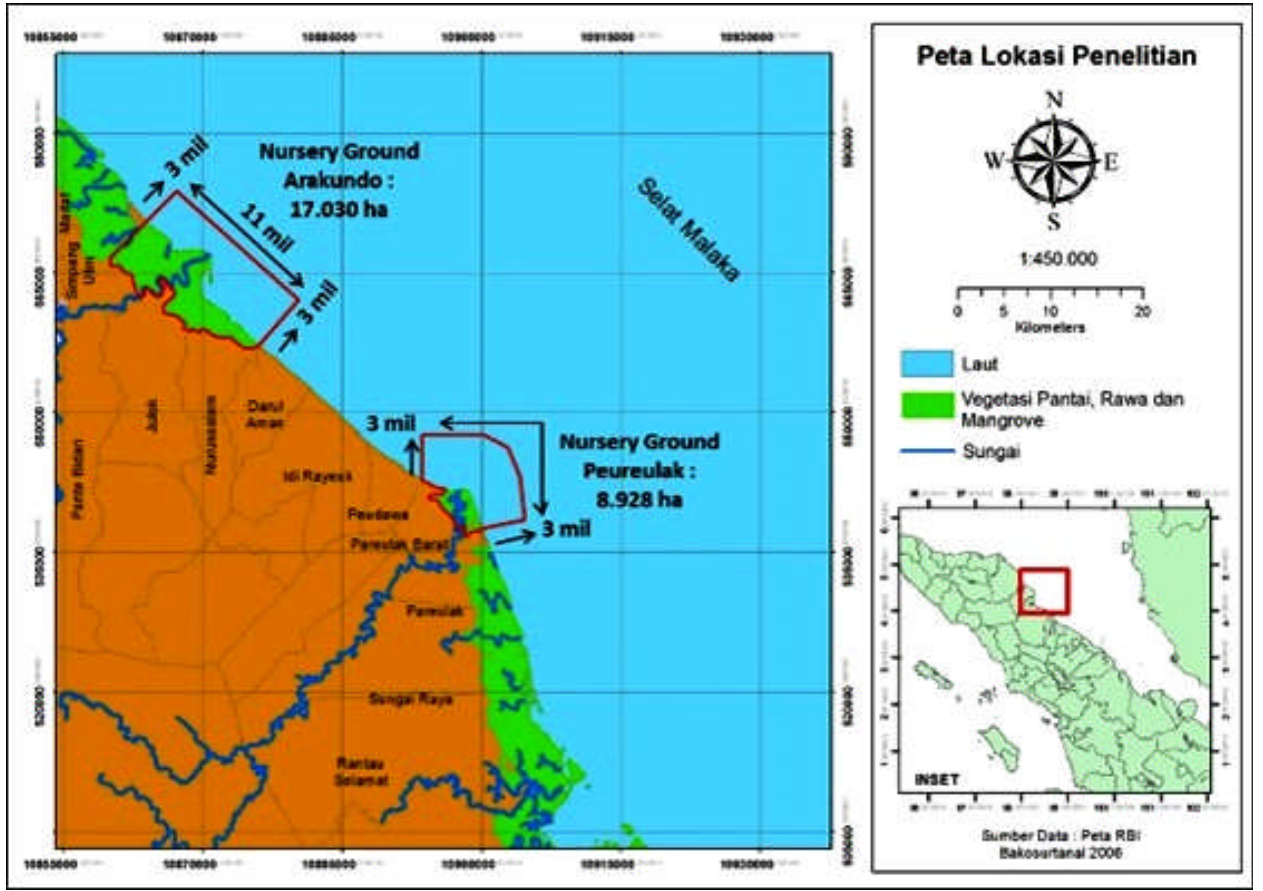

Gambar 5. Daerah asuhan dan luasan area konservasinya di perairan Aceh Timur. Figure 5. Nursery ground and its area of conservation in East Aceh waters.

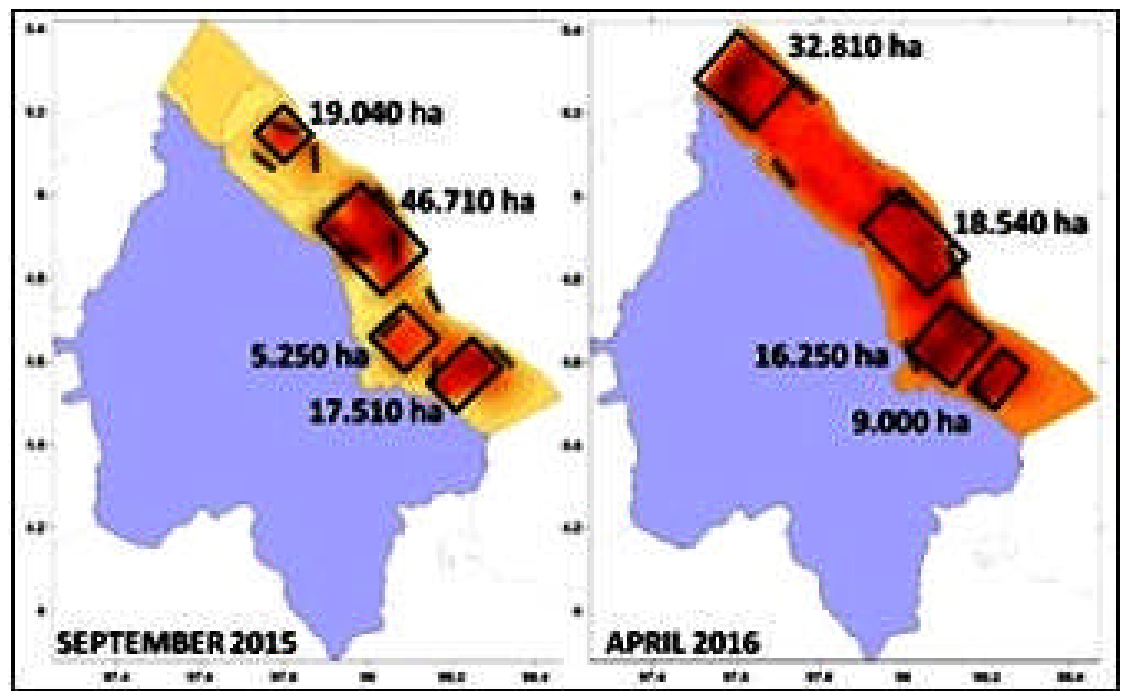

Gambar 6. Peta daerah konservasi induk udang windu untuk bulan April dan September.

Figure 6. Map of adult tiger shrimp conservation area for April and September.

Penutupan daerah dan musim penangkapan bertujuan untuk memelihara siklus pertumbuhan udang, agar tidak terjadi pemutusan terhadap siklus yang dapat mengakibatkan penurunan populasi dan kepunahan udang windu. Penutupan musim penangkapan tidak boleh terlalu lama, sebab akan menimbulkan masalah ketenagakerjaan bagi nelayan yang mata pencahariannya sepenuhnya pada kegiatan penangkapan. Pada saat operasionalnya, pelaksanaan peraturan penutupan daerah dan musim penangkapan harus banyak memanfaatkan peran serta masyarakat nelayan itu sendiri, terutama dalam pelaksanaan patroli atau pengawasannya.

3. Revitalisasi dan pengembangan kelembagaan nelayan. Saat ini pada masyarakat pesisir Aceh Timur, masih berlaku kelembagaan adat yang menjaga sumber daya pesisir dan laut, yang dikenal dengan istilah "Panglima Laot". Sistem tradisional ini bertujuan mengutamakan keharmonisan sosial dan mengurangi potensi konflik antar komunitas dalam pemanfaatan sumber daya laut. Salah satu bentuk norma lokal 
yang disepakati adalah sistem Panglima Laot melarang penggunaan alat penangkapan ikan yang merusak, seperti jaring (misalnya: jaring dengan ukuran mata jaring kecil), untuk mempertahankan keutuhan terumbu karang. Hal ini menguntungkan penduduk dengan hasil tangkapan ikan delapan kali lebih banyak dari hasil tangkapan biasa.

Panglima Laot Lhok merupakan wadah sekaligus basis masyarakat nelayan lokal untuk membangun kesepakatan bersama dalam mengatur dan mengawasi pelaksanaan norma dan ketentuan tatacara pengelolaan sumber daya perikanan yang lebih bertanggungjawab dan berkelanjutan. Kondisi ini dikuatkan oleh pemerintah daerah setempat melalui SK Bupati yang mengatur tugas, fungsi dan wewenang lembaga adat panglima laot di bidang pengawasan dan pelestarian sumber daya.

Pengaruh dan wewenang Panglima Laot Lhok saat ini cenderung tergerus oleh perkembangan sosialpolitik dan modernisasi di bidang perikanan. Dipihak lain, Panglima Laot Lhok tetap merupakan sebuah identitas masyarakat pesisir Aceh yang keberadaan dan peranannya tidak terbantahkan dalam pengembangan perikanan yang lebih berkeadilan dan lestari di Aceh. Oleh karena itu, partisipasi aktif nelayan perlu ditumbuhkan dan dikembangkan kembali, sehingga mampu meningkatkan kesadaran nelayan untuk mentaati peraturan yang yang telah ditetapkan, rasa memiliki dan tanggungjawab dalam menjaga kelestarian sumber daya ikan dan produksinya. Bentuk pengelolaan sumber daya udang dengan berbagi tanggungjawab dan/atau kewenangan diantara pemerintah dan pemanfaat/masyarakat lokal disebut ko-manajemen. Anuchiracheeva (2018) menyatakan bahwa ko-manajemen merupakan perubahan dari bentuk manajemen top-down yang terpusat ke strategi baru, dimana nelayan bersamasama mengelola sumber daya ikan dengan pemerintah. Selanjutnya Anuchiracheeva (2018) menyatakan ko-manajemen bukan teknik pengaturan, tetapi lebih bersifat strategi manajemen partisipatif yang fleksibel dan mampu menyediakan dan memelihara sebuah forum partisipasi, pembuatan aturan, manajemen konflik, pembagian kekuasaan, kepemimpinan, pengambilan keputusan, pengembangan pengetahuan di antara pengguna sumber daya, dan pemerintah.

\section{KESIMPULAN DAN REKOMENDASI Kesimpulan}

Daerah Kuala Arakundo dan Kuala Peureulak mempunyai kepadatan post larva Penaeidae dan kepadatan juveniludang windu yang tinggi, sehingga distribusi kelimpahan secara spasial dari udang windu tinggi, yaitu berkisar antara 10-130 ekor $/ \mathrm{m}^{2}$ (10$167.000 \mathrm{~g} / \mathrm{ha}$ ). Berdasarkan aspek sosialkelembagaan masyarakatnya menunjukkan adanya kehendak bersama (common will) masyarakat untuk melestarikan sumber daya perikanan melalui pengembangan konservasi sumber daya udang windu tersebut. Oleh karena itu, pengembangan konservasi sumber daya udang windu di perairan-perairan pantai Timur diusulkan berupa "Tipe Perlindungan Terbatas", baik terhadap daerah asuhan maupun daerah pemijahannya. Pelindungan daerah asuhan dan pembesaran (nursery ground) udang windu meliputi: (1) daerah sodetan Arakundo-Kuala Arakundo-Kuala Geulumpang seluas 17.030 ha dengan waktu penutupan bulan Febuari-Maret, dan (2) Kuala Peureulak 8.928 ha dengan waktu penutupan JuliAgustus. Perlindungan daerah induk/pemijahan berkisar antara 2-12 mil dari garis pantai dan kedalaman 20-50 m. Untuk (1) Daerah Madat (Krueng Too)-Arakundo (luas $32.810 \mathrm{ha}$ ) dan Langsa-Aceh Tamiang (25.250 ha) untuk April, (2) Daerah PeudawaPeureulak seluas 46.710 ha untuk September.

\section{Rekomendasi}

Dalam upaya pengelolaan dan konservasi sumber daya udang windu perlu langkah-langkah pendukung, agar kelestarian sumber daya udang windu di pantai timur Aceh dapat dijamin. Langkah-langkah tersebut antara lain: (a) Pengendalian dan pemulihan degradasi lingkungan melalui pengendalian erosi bagian huluhilir, dan menjaga serta merehabilitasi hutan mangrove, (b) Pengendalian penyebaran penyakit dengan pendekatan kehati-hatian untuk pengembangan budidaya udang vanamei guna meminimalisir resiko terpaparnya penyakit pada udang windu (c) pengendalian penangkapan juvenil udang windu melalui pelarangan beroperasi tangkap semacam trawl (pukat langgih daan layang), dan (d) revitalisasi dan pengembangan kelembagaan nelayan.

\section{PERSANTUNAN}

Penelitian ini merupakan konstribusi dari kegiatan hasil penelitian selama tahun 2014-2016 dengan judul "Penelitian Kawasan Konservasi induk udang windu (Penaeus monodon) di pantai Timur Aceh, Kabupaten Aceh Timur" di Balai Penelitian Pemulihan dan Konservasi Sumber daya Ikan, Jatiluhur (BP2KSI), Balitbang Kelautan dan Perikanan, Jakarta. Kami Ucapkan terimakasih juga ditujukan kepada Kepala BRPSDI atas dorongan dan kebijakannya, sehingga penelitian ini berjalan lancar dan baik. 


\section{DAFTAR PUSTAKA}

Anshary, H., \& Sriwulan. (2016). deteksi white spot syndrome virus (WSSV) dan monodon baculo virus $(M B V)$ secara simultan pada induk udang windu (Penaeus monodon) dari perairan Makassar dan sekitarnya dengan Teknik Duplex PCR. Laboratorium Parasit dan Penyakit Ikan, Program Studi Budidaya Perairan, Jurusan Perikanan, Fakultas IImu Kelautan dan Perikanan, Universitas Hasanuddin. 13 p. (diunduh 5 September 2016).

Anuchiracheeva, S. (2018). Fisheries Comanagement. The Southeast Asian Fisheries Development Center. http://www.unepscs.org/ Refugia_Training/Managing Fisheries Refugia in the South China Sea/20-Comanagement-FisheriesSouth-China-Sea.ppt Diunduh 31 Oktober 2018.

Bridgewater, P., Kim, R. E., \& Bosselmann, K. (2015). Ecological integrity: A Relevant Concept for International Environmental Law in the Anthropocene? Yearbook of international Environmental Law, 25 (1): pp. 61-78. https:// doi.org/10.1093/yiel/yvv059.

Chan, T. Y. (1998). Shrimp and prawn. in Carpenter, K. E. \& V. H. Niem. (Ed.). 1998. FAO Species identification guide for fishery purposes-the living marine resources of the Western Central Pacific Vol. 2 cephalopods, crustaceans, holothurians and sharks: FAO. Rome, 687-1396.

Dartoyo, A.A. (2004). Model pengelolaan wilayah pesisir kabupaten berbasis digital (Studi kasus: Kabupaten Cilacap Jawa Tengah). Disampaikan dalam Temu Alumni MPKD 9-11 September 2004. $24 \mathrm{p}$.

Direktorat Konservasi kawasan dan Jenis Ikan. (2012). Pedoman pedoman teknis evaluasi efektivitas pengelolaan kawasan konservasi perairan, pesisir dan pulau-pulau kecil. Direktorat Konservasi Kawasan Dan Jenis Ikan-Kementrian Kelautan dan Perikanan. Jakarta. $45 \mathrm{p}$.

Fahmi, Z., Hedianto, D.A., Suryandari, A., \& Tjahjo, D.W.H. (2017). Laporan survey akustik pendugaan distribusi spasial kelimpahan dan biomass udang windu (Penaeus monodon) di Perairan Aceh Timur, $N A D$. Makalah Unpublish.

Fitri, R., \& Iswahyudi. (2010). Evaluasi kekritisan hutan magrove di Kabupaten Aceh Timur. J.Hidrolitan, 1(2), 1-9.
Ganjoor, M. (2015). A short review on infectious viruses in cultural shrimps (Penaeidae Family). Fish Aquac J, 6(3), 11. DOI: 10.4172/21503508.1000136 .

Hargiyatno, I.T., Sumiono, B., \& Suharyanto. (2013). Laju tangkapan, kepadatan stok dan beberapa aspek biologi udang jerbung (Penaeus merguiensis) di perairan Dolak, Laut Arafura. BAWAL, 5(2), 123-129. DOI: http://dx.doi.org/ 10.15578/bawal.5.2.2013.123-129.

Haryanti, Wardana, I. K., Permana, G. N., Fahrudin, Moria, S. B., \& Mahardika, K. (2009). Selektif breeding udang windu Penaeus monodon: studi karakter tumbuh cepat, toleran terhadap WSSV dan SPF (specific pathogen free). Aquacultura Indonesiana, 10(2), 75-84.

Hedianto, D. A., Suryandari, A., \& Tjahjo, D. W. H. (2016). Dinamika populasi dan status pemanfaatan udang windu Penaeus monodon (Fabricus, 1789) di Perairan Aceh Timur, Provinsi Aceh. J. Lit. Perikan. Ind, 22(2), 71-82. DOI: http://dx.doi.org/ 10.15578/jppi.22.2.2016.71-82.

Hedianto, D. A., Suryandari, A.,\& Tjahjo, D. W. H. (2017). Aspek biologi, sebaran, dan daerah asuhan udang Metapenaeus dobsoni (MIERS, 1878) di Perairan Aceh Timur. J. Lit. Perikan. Ind, 23(3),153-166. DOI: http://dx.doi.org/10.15578/ jppi.23.3.2017.153-166.

Indriatmoko, Hedianto, D.A., Suryandari, A., Nurfiarini, A., \& Tjahjo, D.W.H. (2017). Genetik udang windu di pantai Timur Kabupaten Aceh Timur. Makalah Unpublish.

Kembaren, D.D., \& Nurdin, E. (2013). Dinamika populasi dan tingkat pemanfaatan udang windu (Penaeus monodon) di perairan Tarakan, Kalimantan Timur. J. Lit. Perikan. Ind, 19(4), 221226. DOI: http://dx.doi.org/10.15578/ jppi.19.4.2013.221-226.

Lante, S., Laining, A., \& Parenrengi, A. (2014). Performa reproduksi induk udang windu (Penaeus monodon Fab.) jantan alam dan domestikasi tambak. In Prosiding Forum Inovasi Teknologi Akuakultur (pp. 693-700). Jakarta: Indonesia. Pusat Penelitian dan Pengembangan Perikanan Budidaya, Kementerian Kelautan dan Perikanan.

Maskur, Hastuti, M. S., Taukhid, Lusiastuti, A. M., Sugiani, D., Nurzain, M., Murdati, D. R., Rahman, 
A., Simamora, T. D., \& Ismilarni, T. (2014). Buku Saku Pengendalian Hama dan Penyakit Ikan. Direktorat Kesehatan Ikan dan Lingkungan. Direktorat Jenderal Perikanan Budidaya, Kementerian Kelautan dan Perikanan. Jakarta: 216 p.

Motoh, H. (1985). Biology and ecology of Penaeus monodon. In Taki Y., Primavera J. H. and Llobrera J. A. (Eds.). Proceedings of the First International Conference on the Culture of Penaeid Prawns/ Shrimps, 4-7 December 1984, Iloilo City, Philippines (pp. 27-36). Iloilo City, Philippines: Aquaculture Department, Southeast Asian Fisheries Development Center.

Nurdin, E., \& Kembaren, D.D. (2015). Parameter populasi udang putih (Penaeus merguiensis) di perairan Sampit dan sekitarnya, Kalimantan Tengah. BAWAL, 7, 2, 103-109. DOI: http:// dx.doi.org/10.15578/bawal.7.2.2015.103-109.

Nurfiarini, A., \& Adrianto, L. (2015). Penilaian jasa penyedia habitat asuhan melalui pendekatan keterkaitan mangrove dan perikanan: Studi Kasus Di Segara Anakan. Prosiding Forum Nasional Pemulihan dan Konservasi Sumber daya Ikan $V$. Balai Penelitian Pemulihan dan Konservasi Sumber Daya Ikan. KNV 25, 245-252.

Nurfiarini, A. (2015). Kriteria sosial-ekologi dalam penetapan kawasan suaka perikanan (Fish Sanctuary) di ekosistem estuari tropis. Prosiding Forum Nasional Pemulihan dan Konservasi Sumber daya Ikan - V. Balai Penelitian Pemulihan dan Konservasi Sumber Daya Ikan. KL 03: 435448.

Nurfiarini, A., Hedianto, D.A., \& Tjahjo, D.W.H. (2017). Pemetaan partisipatif persepsi masyarakat terhadap pengembangan kawasan perlindungan induk udang windu di Aceh Timur. Makalah Unpublish.

Promonowibowo. (2003). Kepadatan udang penaeid di perairan Semarang dan sekitarnya. Tesis. Program Pasca Sarjana, Undip. Semarang. 65 p.

Pusat Data dan Informasi Kelautan dan Perikanan. (2018). Laporan Ekspor Komoditi Perikanan Indonesia Berdasarkan Wilayah Propinsi 20122018 (Kertas Kerja). Kementrian Kelautan dan Perikanan. Jakarta.

Reza, M.I.H. (2009). Index of Ecological Integrity: What should be the approach for regional sustainable management planning? "Bridging GIS, Landscape Ecology and Remote Sensing for Landscape Planning"-GISLERS Summer School, 3 July-14 July 2009, Centre for Geoinformatics, University of Salzburg, Austria. https:// www.researchgate.net/publication/236880711 Diunduh, 31 Oktober 2018.

Suman, A., \& Umar, C. (2010). Dinamika populasi udang putih (Penaeus merguiensis de Mann) di perairan Kotabaru, Kalimantan Selatan. J. Lit. Perikan.Ind., 16, 1, 29-33. DOI: http://dx.doi.org/ 10.15578/jppi.16.1.2010.29-33.

Suryandari, A., Hedianto, D. A., \& Tjahjo, D. W. H. (2018). Karakteristik biologi dan daerah asuhan udang windu (Penaeus monodon Fabricus, 1798) di Perairan Aceh Timur. J. Lit. Perikan. Ind., 24, 2, 105-116. DOI: http://dx.doi.org/10.15578/ jppi.24.2.2018.105-116.

Suryandari, A., Tjahjo, D.W.H., Nurfiarini, A., Fahmi, Z., Hedianto, D.A., Romdon, S., \& Kuslani, H. (2015). Penelitian kawasan Induk udang windu (Penaeus monodon) di pantai Timur Aceh, Kabuoaten Aceh Timur. Laporan Akhir 2015. Balai Penelitian Pemulihan dan Konservasi Sumber daya Ikan, Jatiluhur. $83 p$.

Sugama, K., Haryanti, Benzie, J. A. H., \& Ballment, E. (2002). Genetic variation and population structure of the giant tiger prawn, Penaeus monodon, in Indonesia. Aquaculture 205, 37-48.

Tirtadanu, Suprapto \& Ernawati, T. (2016). Laju tangkap, komposisi, sebaran, kepadatan stok dan biomasa udang di Laut Jawa. J.Lit.Perikan.Ind., 22, 4, 243-252. DOI: http://dx.doi.org/10.15578/ jppi.22.4.2016.243-252.

Tjahjo, D.W.H., Hedianto, D.A., Suryandari, A., Nurfiarini, A., Fahmi, Z., Indriatmoko, Romdon, S., \& Kuslani, H. (2016). Penelitian kawasan Induk udang windu (Penaeus monodon) di pantai Timur Aceh, Kabuoaten Aceh Timur. Laporan Akhir 2016. Balai Penelitian Pemulihan dan Konservasi Sumber daya Ikan, Jatiluhur. $102 \mathrm{p}$.

Tjahjo, D.W.H., Suryandari, A., Hedianto, D.A., Romdon, S. \& Muryanto, T. (2014). Penelitian Konservasi Udang Windu (Penaeus monodon) di Pantai Timur Aceh, Nangroe Aceh Darussalam. Laporan Akhir 2014. Balai Penelitian Pemulihan dan Konservasi Sumber daya Ikan, Jatiluhur. 91 p. 
Tjahjo, D.W.H., \& Suryandari, A. (2013). Sebaran horizontal juvenil udang di perairan Laguna Segara Anakan. J. Lit. Perikan. Ind., 19, 3, 131-137. DOI: http://dx.doi.org/10.15578/ jppi.19.3.2013.131-137

Tjahjo, D.W.H., \& Suryandari, A. (2016). Kajian ekosistem perairan Laguna Segara Anakan untuk pengembangan konservasi sumber daya udang. Prosiding Forum Nasional Pemulihan dan Konservasi Sumber daya Ikan - V. Balai Penelitian Pemulihan dan Konservasi Sumber Daya Ikan. KNV 11: 95-106.

Toro, A.V., \& Sukardjo, S. (1990). The relative condition factor and carapace length-weight relationship of 'udang windu' Penaeus monodon Fabriaus in THK Segara Anakan Mangrove Waters, Cilacap, Central Java, Indonesia. J. mar. biol. Ass. India, 32,1\&2, 150-153.

Wagiyo, K. \& Amri, K. (2015). Stok dan kondisi habitat daerah asuhan beberapa jenis krustaceae di
Segara Anakan. J. Lit. Perikan. Ind., 21(2), 7178. DOI: http://dx.doi.org/10.15578/ jppi.21.2.2015.71-78.

Wedjatmiko. (2009). Hasil tangkapan dan aspek biologi udang kelong (Penaeus sp.) di perairan Barat Aceh. J. Lit. Perikan. Ind., 15, 2, 133-140. DOI: http://dx.doi.org/10.15578/ jppi.15.2.2009.133-140.

Yudiantari, L.P.E. (2002). Ekowisata sebagai alternatif dalam pengembangan pariwisata yang berkelanjutan di Desa Wongaya Gede, Bali. Thesis Pasca Sarjana. Jurusan IImu Lingkungan Universitas Diponegoro. (Tidak dipublikasikan).

Zakirah, R.Y., Handoyo, K.,\& Djohan,T.S. (2003). Distribusi dan densitas udang windu (Penaeus monodon) dan udang putih (Penaeus merguiensis) di kawasan hutan mangrove Tanjung Banawa, Donggala, Sulawesi Tengah. Teknosains Seri A: IImu Pengetahuan Alam, 16, 2, 255-269. 